\title{
The Idea of Mysticism in the Writings of Andrew Harvey and Pico Iyer
}

\author{
Shruti Mishra \\ M.A English \\ Department of English and Modern European Languages \\ University of Lucknow \\ Lucknow, Uttar Pradesh, India \\ shrutim9628@gmail.com
}

\begin{abstract}
This paper deals with idea of mysticism represented in form of Buddhist Philosophy. I will be discussing the writings of Andrew Harvey and Pico Iyer. Both of them are commendable travel writers, they have extensively travelled and wrote about Buddhism. I will be comparing the writings of both and the way they looked at Buddhism and its philosophy for the welfare of people. A Journey in Ladakh by Andrew Harvey and Sun After Dark by Pico Iyer, both of them talk of about Buddhist dominant regions and its effect on people. The difference between the two is that, the writings of Andrew Harvey is more spiritual whereas Pico Iyer is more technical and political. Both of them express their special bond with India and its people. They talk about the peculiarities of people, the culture and cuisine.
\end{abstract}

Keywords- Mysticism, Buddhist Philosophy, travel writing, people, culture, religion, spirituality, political scenario, India.

When we talk about travel writings, the first feeling that arises in our mind and heart is the curiosity to know about a new place, the peculiarities of that place, to know a different 
culture, to meet different people, to enjoy the essence of a different place altogether. The main motive of travel writings for me is to come out of our comfort zone in order to experience something unusual for us, which might be usual for someone else. The travel writings do not have high literary value. Such writings reveal writer's feelings, where the writer expresses his connection with a particular place and the reason behind why that particular place attracted him and more specifically what compelled him to write an account of his journey. The written account of the journey is representative of the writer's personality and his perception towards different aspects of life together how a person should be welcoming towards the new experiences coming forward in life. It shows the extent of writer's imaginativeness. Travel writing is a sort of monologue with the embellishment of slides and pictures represents before its readers. There can be occasional pieces of writing of a comparatively transitory or ephemeral nature. When looked from the point of view of its purpose then it is basically representative of the unusualness of the manner of writing and of the writer's personality. Most importantly it conveys personally and informally the information related to the journey, it merely consists of travel or expedition involving spatial displacement. Primarily it is written in Prose form. It is very informative and arouses feelings in the reader, the reader comes to know about the food, facilities for accommodation of that place together with the peculiarities of that destination and modes available of travel.

Most early examples of travel literature includes Pausanias' Description of Greece in the $2^{\text {nd }}$ century CE, the Journey Through Wales (1191) and Description of Wales (1194) by Gerald of Wales, and the travel journals of IbnJubayr (1145-1214) and Ibn Battuta (13041377), both of them recorded their travels across the known world in detail. The genre of travel literature was a very common genre in medieval Arabic Literature. It was popularized during the Song dynasty (960-1279) of medieval China. Earlier it was called 'travel record literature'. It was often written in narrative, prose, essay and diary format. Travel writers such 
as Fan Chengda (1126-1193) and XuXiake (1587-1641), incorporated the essence of geographical and topographical information into their writing, while the 'daytrip essay' Record of Stone Bell Mountain by the well known poet and statesman Su Shi (1037-1101) presented a philosophical and moral argument as its central purpose.

One of the earliest records of pleasure in travel, of travelling for the sake of travel and writing about it is of Petrarch's (1304-1374) ascent of Mount Ventoux in 1336. He made use of allegorical comparison between climbing the mountain and his own moral progress in life. MichaultTaillevent, a poet for the Duke of Burgundy, travelled through the Jura Mountain in 1430, he recorded his personal reflections together with his horrified reaction to the sheer rock faces, and the terrifying thunderous cascades of mountain streams. Antoine de la Sale (c. 1388-c. 1462), author of Petit Jehan de Saintre, climbed to the crater of a volcano in the Lipari Islands in 1407 , leaving the imprints of his experience on the reader. In the $18^{\text {th }}$ Century, travel literature was commonly known as the book of travels, which mainly consisted of diaries. In $18^{\text {th }}$ century Britain, almost every famous writer wrote a travelogue. Captain James Cook, a British explorer wrote about his expeditions to new found lands. Alexander von Humboldt's wrote about his expeditions to America, he also acted as a great influencer for Charles Darwin.

Travel writings are often linked with History, including all sorts of exploration and adventures written in its non-literary exposition, whereas in terms of literary exposition they are often linked with Autobiography and experiences which are representative of the revelation of personality. For example- Gulliver Travels, which is a satire on the ongoing political scenario at the time of Jonathan Swift. It is brought out under the metaphor of travelogue. This book brought out the follies and foibles and the hypocrisy of the period in a very intellectual manner. Whereas Heaven's Lake by Vikram Seth, it is written in a sort of autobiographical format where he expresses his curiosity and his satisfaction with his life. 
Travelogue is a sort of fantasy described by the writer or represented as an exposition of the facts, it is the genre of literature which has recorded facts and hence presented to the reader very categorically. It is the literature of artistic presentation of recorded impressions and feelings of writer during his travel. The major function of this genre is journalistic motivation. It persuades the reader in order to understand history with a fresh point of view. It inspires the reader personally, spiritually to fulfill ones philosophical motives and aspirations.

The first travelogue which I will be discussing in this paper is "A Journey in Ladakh" written by Andrew Harvey. It was published in 1983. Andrew Harvey was born in 1952 in Coimbatore, India. He is a British writer, a religious scholar and a teacher of mystic tradition. He brought up his philosophy of mysticism in his non-fictional work "A Journey in Ladakh". He is the author of more than 30 books, including, The Hope, A Guide to Sacred Activism, The Direct Path, and the critically acclaimed Way of Passion: A Celebration of Rumi, The Return of the Mother and Son of Man. He was the subject of the 1993 BBC documentary "The Making of a Modern Mystic" and is the founder of the "Sacred Activism" movement. Harvey conducts workshops on Sacred Activism, where he teaches his students the amalgamation of the teachings of Rumi, together with Yoga and certain other activities which lead to deeper spiritual awareness. He was placed at number 33, in the Watkins' Mind Body Spirit magazine, among the 100 Most Spiritually Influential Living People in 2012. He was also nominated for the Templeton Prize, in 2012. It was later received by Dalai Lama.

It is very evident from his writings that, he is a great scholar and an avid researcher of mystic tradition. He envisages true spirituality to enjoy the divinity of materialistic life through proper spiritual practice by awakening their soul. Such kind of practice can be achieved through any form and through any kind of religious tradition. There are few poets and religious figures whom Andrew Harvey considers have certain kind of influential spiritual appeal. While discussing his novel "A Journey in Ladakh", I found that he 
mentioning the following writers in order to bring up the mystical and spiritual aspects of Ladakh. Gautam Buddha holds the most prominent place in his work as he majorly talks about the Buddhist Philosophy. He communicates the teachings of Buddha with the reader with reference to "Dhammapada". He also discusses the teachings of Jesus, as portrayed in the "Gospel of Thomas". He also mentions few lines from Rumi's poetry, who was a $13^{\text {th }}$ century Sufi poet. He even makes use of Kabir's writings, who was a $15^{\text {th }}$ century Indian poet. He also acknowledges the teachings of Ramkrishna, a $19^{\text {th }}$ century Hindu Sadhu. He was also the Guru of Swami Vivekananda, and the founder of Ramkrishna Mission which works in this aspect. And last but not the least, Sri AurobindoGhosh, who is the great mystic leader and a Hindu philosopher sage of $20^{\text {th }}$ century, of India. Andrew Harvey also emphasized the divine feminity presented by the Virgin Mary, Goddess Kali, the Black Madonna and the Mother Earth. Andrew Harvey described sacred activism as "the product of the union of a profound spiritual and mystical knowledge, understanding, and compassion, peace and energy, with focused, wise, radical action in the world".

Andrew Harvey was born in Coimbatore, India. Hence he had a very obvious fascination for India. Throughout in his travelogue, it is very evident that although he had achieved everything in his life still there was something major missing in his life, apparently this something can only fulfilled by the spiritual awakening of the soul. Harvey was completely disillusioned from his life. He was deeply interested in Mysticism, Buddhism and the essence of Sufism. He was deeply interested in studying the psychology of humans in order to understand the essence of life or rather what makes it meaningful. He used to teach the "Madness of Shakespeare" at Oxford University, it was an attempt to study the psychology of Shakespeare in order to understand why the characters of his plays are framed as they are. We see many characters in this book advising the writer to visit Ladakh in order to experience the missing elements of his life. Ladakh is the starting point for him to study 
and experience the mystical dimensions of religion and life. According to him, the idea of mysticism is brilliant but it does not mean that the person has to reject all the material aspects of his life, it is just about having a spiritual dimension toward our life and live our life with an open heart. Andrew Harvey accepted the Mahayan Buddhism in his life. He is also a poet and published his first poem at the age of 21 . He is extremely vivid, concrete and verbose in his view and his writings.

Ladakh is heavily influenced by the Tibetian culture as Ladakh itself was earlier a part of Tibet. He expresses in the acknowledgment of the book that the Tibetian tradition is one of direct oral transmissions and so his account of the teachings is necessarily limited. The book is divided in three sections namely, The Beginning, An Exploration and To the Rimpoche, in order to describe his journey of his fate took him to Ladakh and how Ladakh contributed towards transforming his life in order to make him spiritually awakened. He dedicated his book to Iris Murdoch, who was a British novelist and philosopher. She is a well known name for using themes likes good and evil, sexual relationships, morality, and the power of the unconscious, her prominent ideas were about the sovereignty of the good together with the idea of perfection.

Andrew Harvey attempts to talk about topographical, geographical, political and spiritual aspects of Ladakh. In the first section of the book he talks about what compelled him to move towards a mystic life. He begins by taking about Tibet and the influence of Dalai Lama. He expresses that he was in Oxford during the early 1970s when he became interested in Buddhism. He mentions that "My life was full of confusion and distress of every kind, and I found in Buddhist philosophy a way of thought that enthralled me by its calm and radical analysis of desire, its rejection of all the self-dramatising intensities by which I lived, and its promise of a possible, strong, and unsentimental serenity". He read all sorts of texts extensively for his spiritual awakening, like Dhammapada, the Heart and Diamond Sutras, 
the books of Conze and Watts and Herrigel, including the essays of Suzuki, and other texts from all different Buddhist traditions.

He read widely and says that he understood little of what he read as he was too fascinated by the turbulence of his own life in order to want or to be able to take on the responsibility of living a philosophy as exacting and un-self-flattering as Buddhism. In this aspect he found no teacher and hence followed no discipline. He talks about the calmness and peacefulness on the face of Buddha, he never experienced anything like this ever in Western art, that was something which he loved from his mind but lacked in his life.

The themes which he attempts to bring up to the reader through this spiritual work for the welfare of humanity are, the need of simplicity in this highly materialistic world. Through the character of Jamyang, he talks about how the American society is completely materialistic, there is no place for spirituality, the American men and women are hollow rom their soul, it is very evidently represented in the character of Jamyang's wife. He talks about taboos like love and sex in Tibetan tradition or rather in Ladakhi culture, the most interesting part is that these words are not considered as taboo in Ladakh. The author finds the extinction of old Tibet metaphorically as well as figuratively, he talks about the flexibility of belief together with the amalgamation of the traditional Tibetan society with modern views. He takes up the political scenario of the place to make his readers aware of how the politics of Kashmir has contributed towards the destruction of the cultural heritage of Ladakh.

While coming on terms with the teachings of Gautam Buddha, the writer is reminded of the calmness and peacefulness on the face of Lama, that smile made him experience the immense happiness. Hence he moves forward to in the quest of gaining this sort of happiness. He says that "Laughter is the beginning of wisdom". Ladakh is the last place where we can see something of what Tibet must have been like, now that Buddha is open only to the very rich. And Ladakh is a wonderful place in its own right too. This place can make a person 
experience the intensity and any truth in its absolute form. Dreams of meditating Lamas to contributed to a large extent in taking the writer to Ladakh.

He begins by talking about the first sermon of Buddha- that the world is on fire and every solution short of liberation, of Nirvana, is like trying to whitewash a burning house, by this he indicates the materialistic aspect of life which has empowered every soul. He urges his readers to experience this serenity as it offered him great help. It is a rich path, a path that excludes no energy and banishes no perception, one may find whatever he needs. While talking about Nirvana, he says 'A careless pilgrim scatters the dust of his passion more widely'. Buddha teaches that 'Not nakedness, not plaited hair, not dirt, not fasting, or lying on the earth, not rubbing with dust, not sitting motionless, can purify a mortal who has not overcome desires'. By oneself the evil is done and also by oneself the evil is undone, no one can purify another. Men who have not gained treasure in their youth, perish like old herons in a lake without fish. According to him Ladakh is the land of high mountain passes; my experience of Ladakh and its people was to be, for me, a pass, into another awareness of reality. He perceives that it is the quality of silence that no words can convey, that silence that sustained over millennia, that silence of snow and rock and water, in which every sound and movement was contained, with which every object in that world was bathed, as if with shining water. It just makes us experience the essence or rather the spirit of true life. While giving an account of his journey, he mentions lines of a ghazal by Rumi, sung by an Iranian, 'Sufi, why are you standing before the door?

What are you looking for?

I am looking, my friend,

For what is impossible to find:

I am looking for a man.' 
These lines convey the idea of humanity among people, which seems hard to find in this modern world. He later talks about Stupa, a building of plaster and brick which has a large cubic foundation and has four stages where each stage of the building symbolizes a different stage of consciousness. Stupa signifies itself as a symbol of Universal Consciousness regarding the Awareness that is Nirvana. The most important lesson which he taught is that the most important thing is to serve others whenever they are in need in order to attain salvation. He talks of the noise of water, shaking in moonlight and starlight, coursing in untidy channels through darkening corn, between moon-washed poplars and willows, bringing a flickering life to paths lined by shrines and small stupas that hardly seems solid in the moonlight than the streams that run by them. Writer expresses that on being surrounded by so much water, the mind itself becomes water, hindered by nothing but is abandoned happy.

On contrast, Ladakh does not have the inhuman solitariness of Antarctica or the Sahara; it is completely filled with marks of human love and prayer at every spot. Human companionship moves the writer the most. The spirit of Ladakh has changed it into a shrine, an object of worship! Whose guardian is the ever smiling Buddha, radiating peace to the mankind. The writer gives an account of the life of people in the harsh climate of Ladakh in order to bring up their simplicity to the reader. He says that most of these people live simply and unsentimentally, they live with few needs, few prides, few vanities. They are tolerant to their old people, to their children, to each other. They are taught by their priests that every living being has been their mother in a previous incarnation, and so they must respect it as their mother, he says that he sees very little cruelty.

Everything is religion in Ladakh in one way or another, by this he does not mean that everything is a mystic. The religion of Ladakhi people is practical, down-to-earth - it has very little to do with the complex refinements of the lamas. He once asked that "Is it a good 
thing to have pride?" Everyone answered "No", without fail, and many added that actually pride is the root of all evil. They say that it is wrong to hurt anyone or anything, and that if you do you will pray for it, in one life or another. An old woman who has been a wife and a farmer all her life said that, "Everything is empty, everything has only a relative meaning. Why then hurt anyone?" And yet this fear of pride, this absence of any sense of competition, has not made the Ladakhi soft, or inefficient - you have only to look across the valley from this window, at all the fields scraped from the rock, to realize how hard they work. They are linked together by their faith in their Rimpoches, and their head lamas. It is easy to look at this faith and say, it is superstitious, it absolves them from all the responsibilities of thought. But they do believe in the power of their holy men, and not only in a supernatural sense. Their belief gives them peace, it is hard to say "And this belief gives them peace" without being either patronizing or skeptical, but when you see and feel this peace, this dignity, day after day in the most ordinary situations, in the way in which an old woman will make you tea, in the way she smiles at you from the fields. The writer is completely moved by it. There is a beauty of life in Ladakh.

Ladakhi humor is not merely a product of exigencies: it is rooted in the practice and philosophy of Buddhism. There is humor in Buddhism which has too often been ignored by Western writers, prone, like Schopenhauer, to see the Buddha as a kind of world-weary super-sophisticated victim of accidie, and Buddhism as a philosophy of sad negation. In fact, the Buddha lived a very active life thoroughly involved with his world. The Buddha even made a joke on his deathbed. When one of his disciples came to him and asked how the world should commemorate him after his death, the Buddha, who had always taught the vanity of fame and the Non-Existence of the Self, took two wooden bowls and put them on top of each other, meaning, "To commemorate any man is to heap the emptiness of fame on to the emptiness of selfhood, to pile one emptiness on another." Being omniscient, he would 
have known that the man would take the shape of the two bowls and make out of it the Buddhist stupa.

Buddhism is, in fact, essentially "comic", in the highest, philosophical, sense. The Buddha taught that all phenomena are, from an "absolute" perspective, non-existent, "empty", that they are all projections of desire, creations of a fictive neurotic Self that can be cured by realizing that it does not "exist", that its true nature is "empty", that all mental, emotional and spiritual constructions are false. The nature of all things and all actions is "dukkha" - suffering, or "unsatisfactoriness". - and it is by realizing, by awakening to, the emptiness of phenomena, that what the Buddhists call "sunyata", freedom from suffering, can be attained. Freedom from suffering, from all suffering, in this life is the aim of Buddhist philosophy and practice. The Buddha did not want men to rest in a mournful clarity about the vanity of the world and the futility of all perceptions; he wanted them to be "awake", to be "Buddha" (the word means "awakened" in Sanskrit), to be free from all hopes and fears, from all desires and constructions of desire. Such a vision is in the deepest sense comic because it denies any final significance to individual striving or tragic awareness, any ultimate importance to the agonies and vicissitudes of the Ego.

There is a special significance to dreams in Buddhist philosophy as well. People can tell future through dreams. He says that if someone sees himself wearing a gold cloth in a dream then he will get big honor. If someone comes to you and says that I have been crossing a river or climbing a mountain or riding a dragon, one can say that this is a very good sign. You will make good spiritual things if someone comes to you and says I have seen a sun rising in my dream without any clouds and I have heard the sound of drums and trumpets, one can say that soon you will be getting some money. If someone comes to you and says that I have been without a hat in my dream and looking into a mirror then one can say that you will suffer. 
On talking about Oracles, the writer expresses that part of my love for Eastern philosophy had been a desire to have done with that inner violence once and for all, to live beyond it in a harmless serenity. But no true transformation can be achieved by a neurotic refusal of a whole side of the psyche. He says that I could not progress until I no longer used my love for the East as a way of pretending to myself that I was not violent and not destructive. He states that he began to understand that the inner usefulness, the psychological value, of the Terrible Deities painted for meditative purposes on the walls of the gompas. The frank portrayal of the horror of anger, desire, greed, and lust for power, they did not merely terrify the onlooker, they gave him an opportunity to confront those parts of his energies which he was repressing, to confront, understand and master them, to turn them, as the Oracle had turned her hysteria, into a power to heal.

Buddhism teaches the transience of all things, a certain calm detachment from others and from oneself. It teaches us not to take ourselves too seriously, and we are taught to believe that there is little ultimate truth in grief or misery. The real wisdom is joy. The real wisdom is happiness. The true wisdom is that of the Buddha who is always shown at peace with all things. There is no tragedy in Ladakhi literature, no concept of tragedy, in fact. There is a Ladakhi saying, "The greatest courage is the courage to be happy." It takes a great courage when you are suffering to see beyond your suffering to the clear relations between things, to the laws that cause and govern your suffering; it takes a great courage to be ruthless towards ones griefs. 


\section{Work Cited/Consulted}

O’Reilly, Jane (11 August 1991). “Soul Searching”.The New York Times.Retrieved 25 April 2010.

Hidden Journey: A Spiritual Awakening, 1991

The Tibetan Book of Living and Dying: A New Spiritual Classic from One of the Foremost Interpreters of Tibetan Buddhism to the West (co-editor), 1992

The Way of Passion: A Celebration of Rumi. North Atlantic Books/Frog, 1994. ISBN 1883319-20-X

The Divine Feminine: Exploring the Feminine Face of God Throughout the World, 1996 ISBN 1-57324-035-4

Light upon light: Inspirations from Rumi. North Atlantic Books, 1996. ISBN 1-55643-206-2 The Essential Mystics: The Soul's Journey Into Truth. Castle Books, 1998. ISBN 0-78580904-X

Mary's Vineyard: Daily Meditations, Readings, and Revelations. With ErykHanut.Quest Bookjs, 1996.ISBN 0835607453.

A Journey in Ladakh: Encounters with Buddhism, 2000. Houghton Mifflin Harcourt, 2000.ISBN 0-618-05675-0.

The Direct Path: Creating a Personal Journey to the Divine Through the World's Traditions, 2001 ISBN 0-7679-0299-8 